\title{
THE OCCURRENCE OF PALYGORSKITE IN \\ THE YUCATÁN PENINSULA: ETHNO-HISTORIC \\ AND ARCHAEOLOGICAL CONTEXTS*
}

\author{
M. SÁNCHEZ DEL RÍø \\ Eurøpean Synchrotron Radiation Facility, BP 220 F-38043 Grenoble Cedex, France
}

M. SUÁREZ

Departamento de Geologia, Universidad de Salamanca, E-37008 Sulamanca, Spain

and E. GARCÍA-R@MER•

\begin{abstract}
Departamento de Cristalografia y Mineralogia, Universidad Complitense de Madrid, E-2804 Madrid, Spain
Palygerskite is a rare clay mineral used by the ancient Mays for foricating the May blue pigment and or ther purposes. It seems to have been obtained from a restricted area in the Yucatan peninsula where important archaelogical sites are found. Geological samples from different localities in this are show a hightent in palygorskite, indicating that this clay is widespread in Yucatan. Combining structural, morphological, compositional and gechemical methods, we analysed the common characteristics of Yucatecan palygorskites, and compared them with palygorskites from other origins around the world. These results can be used for defining a fingerprint of Yucatecan palygorskite to be used in provenance studies orchaelogical artefacts, in particular the May blue pigment.
\end{abstract}

KEYW•R DS: PALYGORSKITE, YUCATÁN, MAYA CULTURE, MAYA BLUE

\section{INTRODUCTION}

The Yucatán peninsula is mainly formed by marine carbonated sediments. A Tertiary calcareous sequence crops out in a large part of Yucatán without significant deformation and appears as a calcareous plateau slightly inclined to the north-west. This is the direction in which the Cenozoic units (Tertiary mainly) showed a gradual retreat of the sea towards the present line of the coast (Morán-Zenteno 1994). This is a karstic zone that does not have water at the surface (rivers or lakes) and the underground water is accessible at sinkholes produce by the falling of the surface rock. These important formations are locally called cenotes (from the Mayan $d z \bullet$, a well venerated by the ancients because it contained water that never saw the light).

This tropical peninsula was densely populated in the past. Archaeological findings have demonstrated that the ancient Maya created complex trade networks (Sabloff and Rathje 1975), systems of water storage and distribution (Scarborough and Gallopin 1994) and a sustainable system of agriculture. Many important Maya archaeological sites can be found in this area, in particular those corresponding to the Puuc (from the Mayan for 'hills') characterized by an architectural ornament at vault level, dating from the Late Classic Period (A 800-1000). 
Palygorskite is known since ancient times in Mesoamerica, in particular in the Mayan Lowlands. There are several fundamental facts that indicate that this material and its properties were very well known by the Maya and that it was linked to sociocultural aspects of the Maya culture. The first fact is that palygorskite (locally known as sacam) is still known amongst the indigenous communities of the Yucatán peninsula (Yucatán and Campeche states) and is use for several applications, including ritual ceremonies (fabrication of candles used on the Day of the Dead), domestic and art craft ceramic production (pottery fabrication in the area of Ticul), and medical treatments. Its use as a curative agent (Bohor 1975) was both external for pain relief in cases of mumps and abdominal pain, and as a drug for dysentery diseases and also for pregnant women (Folan 1969). It is remarkable that palygorskite and other clays are also use in modern pharmacology as an anti-diarrhoeic (Viseras and López-Galindo 1999), as the Maya did more than $\mathbf{1 0 0 0}$ years ago. These traditions, which survived for a number of centuries, also suggest that palygorskite was more intensively use in the past.

The most important use of palygorskite is as the main ingredient in the Maya blue pigment. It is made by embedding an organic colorant (indigo, obtained from the Indig fer suffruticas plant, locally known as añil or xiuquilitl) in the clay matrix of palygorskite. The resulting compound has an extraordinary resistance to chemicals and environmental aggression. The Maya blue was invented by the Maya in the period from the sixth to the eighth century. It has been found in archaeological artefacts all over Mesoamerica, from the Gulf to the Pacific coasts, suggesting that the Maya exported the Maya blue to most Mesoamerican cultures, such as Olmec-Xicalanca, Totonac, Huastec and Aztec. It was also used in Colonial times for the decoration of convents and churches (Reyes-Valerio 1993), at least until the end of the 16th century. Even later, it was employed for decoration of civil buildings in Colonial Cuba (Tagle et al. 1990).

In this work, we study palygorskite samples collected in several locations in the Yucatán peninsula and compare them to other palygorskites from other sources in the world. The Yucatecan samples were not only obtaine from sources well described in the literature, but also from new ones. The analysis of these samples aims to answer the following two questions: (i) Did the Maya mine palygorskite from one or a few well-located sources or, on the contrary, is palygorskite very frequent in Yucatán and could it have been obtained from many places? (ii) Does the Yucatecan palygorskite present mineralogical characteristics different from other origins that could be recognize in archaeological Maya blue?

\section{MATERIALS}

Prior to the retrieval of palygorskite samples, an exhaustive bibliographical search identified the possible historical sources. Many of these sources were studied in an ethno-historic context (Folan 1969; Arnold and Bohor 1975; Bohor 1975; Arnold 2005; Arnold et al. 2007). Using these data, we defined a searching area consisting of a circle of about $40 \mathrm{~km}$ radius, centred on the archaeological site of Uxmal (see Fig. 1). Most of the sites referred to in the literature lie inside this area.

The three most important sites are as follows:

- The cen and Bohor 1975; Bohor 1975) because there is archaeological evidence of its use as a palygorskite mine in ancient times. In our visit to the cente, we collected a sample (labelled Y19) from the debris of extraction work lying on the cente's floor, close to the entrance stair. Inside the cen te there is a small entrance to a contiguous chamber of $\sim 300 \mathrm{~m}^{2}$, the mine, accessible via 


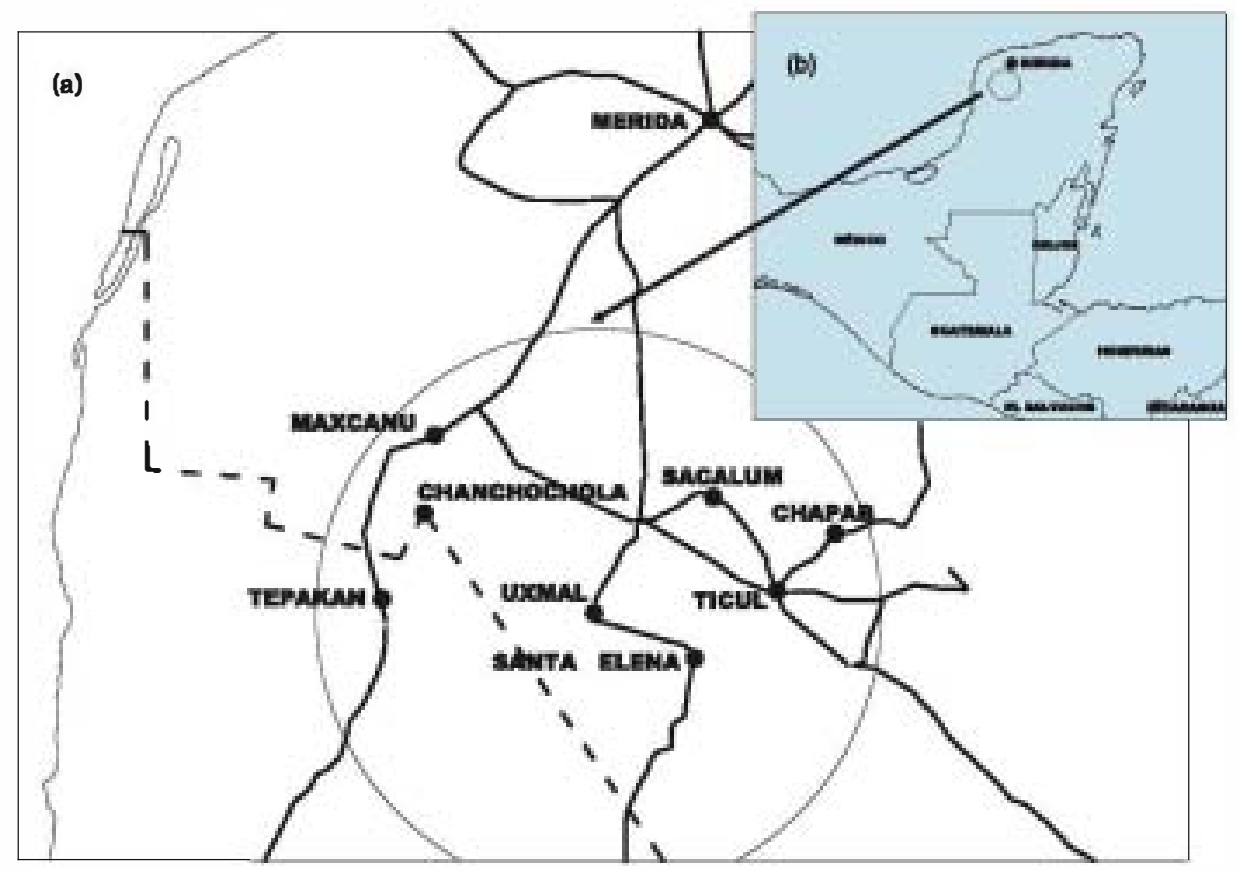

Figure 1 (a) Detail of the region of interest ( $4 \mathrm{~km}$ and the Uxmal site), with indications of some localities. (b) A map of the Gulf of Mexic Gulf: the region of interest is encircled.

a tunnel excavated in the palygorskite deposit (Bohor 1975). There is direct evidence that a high amount of palygorskite was extracted in the past. Local inhabitants informed us that although the mine is not exploited at present, some people occasionally enter to extract palygorskite for fabricating cosmetics. The sample Y8 was obtained from inside the mine.

- The Ticul-Chapab road. There are many sources of palygorskite along this road. They are well known by the potters of Ticul, who use palygorskite as temper for improving the characteristics (resistance to fracture) of their pastes (Arnold 1998). One site was studied in a geological context, sampling from existing prospection wells (Bohor 1975). We were not able to identify these wells. Another site is related to an ancient mine (Arnold 2005). Palygorskite from this zone, obtained from the Ticul potters, was used in recent works (Chiari et al. 2003; Giustetto et al. 2005; Sánchez del Río et al. 2006a). Three places were sampled. The first one, about 3-4 km from Ticul, on the right-hand side when looking in the direction of Chapab, could correspond to the old mine. It is located at coordinates N20 $25.337^{\prime}$ W89 $30.407^{\prime}$. We observed several cave-like holes in the floor, with direct evidence of extraction work in the past. A sample was taken (Y5) from the debris found on the floor. Another sample (Y6) comes from a second place, which is about $2 \mathrm{~km}$ further along the road, at N20 26.493' W89 $28.748^{\prime}$. A third place, about $7 \mathrm{~km}$ from Ticul, is much larger than all the others visited and has clear evidence of massive extraction of sacalum. It is at $\mathbf{N}^{\circ} \mathbf{0}^{\bullet} 26.567^{\prime} \mathrm{W} 89^{\bullet} 28.643^{\prime}$. A sample (Y7) was collected from the tons of debris in this site. For the sake of completeness, we also included in the study another sample (YO) from this zone, used in previous works (Sánchez del Río et al. 2005, 2006a,b; Suárez et al. 2007). 
- Maxcanú. This site, a terrain cut on the railroad, is described by (Bohor 1975). We unambiguously identifie it thanks to the pictures in Bohor (1975) and with the help of local people. The site is at $\mathbf{N} 20^{\bullet} 34.545^{\prime}$ W $89^{\bullet} 54.491^{\prime}$. It presents different rocky, powdered and sedimentary materials. We sampled different points: the sample Yla comes from a sedimentary layer of approximately $2-4 \mathrm{~cm}$. The sample $\mathrm{Y} 1 \mathrm{~b}$ is from a second point from the same layer. The samples Y lc and Yld come from the contiguous bottom and top layers, respectively. The sample Y le comes from another point close to the sedimentary layer. It looks to be the dominant material in the deposit, marke as 'clay' in figure 4 of Bohor (1975). Another layer was found with a very different colour (grey) and consistency (Y1f). Sample Ylg was taken from the other side of the railway.

Two new sites were sampled:

- A sascaber $\left(\mathbf{N} 20^{\bullet} 31.510^{\prime}\right.$ W $\left.9 \bullet^{\bullet} \mathbf{0} 3.015^{\prime}\right)$ close to Chanchocholá. This place is used at present for extacting sascab, calcareous material with good compaction characteristics, used for making roads. Two samples were taken, one from the predominant material (Y2a) and a second one (Y2b) looking very much like the samples Y1 a and Y1b from Maxcanú.

- Sample Y3 was collected in a recent road cut along the new Uxmal-Mérida road $\left(\mathrm{N} 20^{\bullet} 23.336^{\prime} \mathrm{W} 89^{\bullet} 46.172^{\prime}\right)$.

A deposit in the Uxmal-Santa Elena road was cited in Arnold et al. (2007). We could not identify this exact place. Several road cuts exist and we sampled one (Y4) at N20 $20.826^{\prime}$ W89 $9^{\bullet} 2.915^{\prime}$. This work also mentions two other sites: a cen $\bullet$ te in Maní, also visited, but where we could not identify palygorskitic clays, and Mama, a village where we were also unsuccessful in finding the palygorskite source.

We also obtaine materials from a pottery shop in Ticul: a sample of scalum (Y9) and one of $\operatorname{sascab}(\mathrm{Y} 10)$, materials used systematically as temper for pottery. Another sample from Tepakan, Campeche (Y13) was also analysed.

In addition to the Yucatecan samples, for our mineralogical and chemical analyses we used other palygorskites from other origins: Bercimuel (BERC), Esquivias (E11), Torrejón el Rubio (T@R), Los Trancos (TRA) and Níjar (SNE) from Spain; Attapulgus (ATT) from Georgia (USA); and Lisbon (LISL) from Portugal. Most of these have been studied from other points of view (García Romero et al. 2006; Suárez and García Romero 2006).

\section{ANALYTICAL METHODS}

Mineralogical characterization was performed by X-ray diffraction (XRD), using a Siemens D 500 XRD diffractometer with $\mathrm{Cu} \mathrm{K}_{\alpha}$ radiation and a graphite monochromator. The samples used were random-powder specimens. They were powdered, but used 'as found', without any chemical reatment or washing. Powders were scanned in $2 \theta$ from $2^{\bullet}$ to $65^{\bullet}$ with a step of $0.02^{\bullet}$ and $3 \mathrm{~s}$ integration time.

Particle morphology and textural relationships were established by scanning electron microscopy (SEM) and transmission electron microscopy (TEM). SEM observations were performed using a JE L JSM 6400 microscope, operating at $20 \mathrm{kV}$ and equipped with a Link System energy-dispersive X-ray micro-analyser (EDX). Prior to SEM examination, freshly fractured surfaces of representative samples were air-dried and coated with Au under vacuum. TEM observations were performed by depositing a drop of diluted suspension on a grid of $\mathrm{Ni}$ with collodion.

The chemical composition was obtained by analytical electron microscopy (AEM) with TEM, in samples of great purity, using a JE 2000 FX microscope equipped with a double-tilt 
sample holder (up to a maximum of $\pm 45^{\bullet}$ ) at an acceleration voltage of $200 \mathrm{kV}$, with $0.5 \mathrm{~mm}$ zeta-axis displacement and $0.31 \mathrm{~nm}$ point-to-point resolution. The microscope incorporates an Oxford ISIS energy-dispersive X-ray spectrometer (136 eV resolution at $5.39 \mathrm{keV}$ ). Structural formulae for palygorskites have been calculated from the ideal structure, normalized to 42 negative charges. Oxygen was not measured quantitatively. All the Fe present in the samples was considered to be $\mathrm{Fe}^{3+}$, thus neglecting the possible existence of $\mathrm{Fe}^{2+}$, the content of which is usually very low.

The geochemical analyses were performed at the Activation Laboratory in Ontario (Canada). Major elements were obtained by Fusion-Inductively-Coupled Plasma (FUS-ICP) and race elements were analysed using FUS-MS.

\section{RESULTS AND DISCUSSION}

The discussion here follows the different techniques used for obtaining complementary information on the Yucatecan palygorskite. The mineralogical characterization is discussed on the basis of the X-ray diffraction data. Morphological aspects, related to the fibrous structure, are unveiled by scanning electron microscopy (SEM). Electron microscopy was also used, this time in transmission mode (TEM), to obtain quantitative information about the chemical formula of the palygorskites (crystallochemistry). Last, the geochemistry analysis allows us to 'fingerprint' the Yucatecan palygorskites in a wider geological context, using both major and trace element concentrations. When studying archaeological Maya blue pigments, these results can be of great help for rejecting or accepting the hypothesis of Yucatecan provenance of the palygorskite.

\section{Mineralogical characterization and phase purity (X-ray diffraction)}

XRD diffractograms were recorded for all samples, and a semi-quantitative mineral analysis was performed. Table 1 shows the results of the mineral analysis. All samples present a very homogeneous composition, mainly palygorskite and carbonates (calcite and dolomite). Only two samples (Y1d and Ylf) from Maxcanú contain dioctahedric smectites and a third one (Y 1 g) contains small impurities of quartz. The two sascab samples can be described as palygorskitic marls, the sample from Chanchocholá is dolomitic, and the one from Ticul contain both calcite and dolomite. The high purity of palygorskite in most samples is remarkable.

The materials of the Maxcanú deposit are limestones and marls in which there are clay levels in thin layers $(2-4 \mathrm{~cm}$ ), very rich in palygorskite (Yla and Ylb) or in dioctahedral smectite (Y1f). Calcite appears associated both with palygorskite and with smectite. Dolomite has not been identified in this zone.

None of the samples studied present palygorskite in combination with other clays (smectites, sepiolite etc.). The possible occurrence of sepiolite in Yucatán is an interesting matter, because sepiolite has been found in archaeological Maya blue pigments (Gettens 1962; Shepard 1962; Shepard and Gottlieb 1962). However, the presence of sepiolite is always related to blue pigments from the Valley of Mexico and it has never been found, to our knowledge, in Maya blue from the Maya region, an idea advanced by Shepard and Gottlieb (1962): 'It is noteworthy that sepiolite has not yet been found in any Yucatecan or Mayan sample.' The absence of sepiolite in Yucatán implies that the blue pigment containing sepiolite found in some archaeological artefacts does not incorporate Yucatecan palygorskite. We did not find sepiolite in our samples, in agreement with other studies on Yucatecan palygorskite (de Pablo-Galán 1996; Chiari et al. 2003). However, in the literature, the presence of sepiolite has occasionally been 
Table 1 The location of the samples and their mineralogical composition (Q. quartz; C, calcite;

S, smectite; $P$, palyorskite)

\begin{tabular}{|c|c|c|c|c|c|c|c|}
\hline Zone & Location & Sample & $\boldsymbol{e}$ & $C$ & $\boldsymbol{D}$ & $S$ & $P$ \\
\hline \multirow[t]{10}{*}{ West } & \multirow[t]{7}{*}{ Maxca nú } & Yla & - & - & - & - & 100 \\
\hline & & Y1b & - & - & & & 100 \\
\hline & & Ylc & - & 100 & - & - & - \\
\hline & & Y 1d & - & 50 & - & 50 & - \\
\hline & & Yle & - & 100 & - & - & - \\
\hline & & Ylf & - & - & - & 100 & - \\
\hline & & Ylg & $<5$ & 50 & - & - & 46 \\
\hline & \multirow[t]{2}{*}{ Chanchocholá } & $\mathrm{Y} 2 \mathrm{a}$ & - & - & 66 & - & 34 \\
\hline & & $\mathrm{Y} 2 \mathrm{~b}$ & - & - & - & - & 100 \\
\hline & Tepakan & Y13 & - & - & - & - & 100 \\
\hline \multirow[t]{2}{*}{ Uxmal } & Mérida-Uxmal road & Y3 & - & 8 & & - & 92 \\
\hline & Uxmal - Santa Elena road & Y4 & - & 87 & 13 & - & - \\
\hline \multirow[t]{8}{*}{ Ticul } & \multirow[t]{3}{*}{ Ticul-Chapab road } & Y5 & - & - & - & - & 100 \\
\hline & & Y6 & - & - & - & - & 100 \\
\hline & & Y7 & - & - & - & - & 100 \\
\hline & \multirow[t]{3}{*}{ Sacalum } & Y8 & - & - & - & - & 100 \\
\hline & & Y19 & - & - & 100 & - & - \\
\hline & & $\mathrm{Y} \bullet$ & - & - & - & - & 100 \\
\hline & \multirow[t]{2}{*}{ Pottery shop in Ticul } & Y & - & - & - & - & 100 \\
\hline & & Y1॰ & - & 34 & 20 & - & 46 \\
\hline
\end{tabular}

reported in Yucatán, but not in surface outcrops. For instance, traces of sepiolite were found in the Chicxulub crater in Yucatán (Wolfgang et al. 2004), resulting from the impact of a meteorite that has been proposed as a cause of the extinction of the dinosaurs, about 60 million years ago. Isphording and Wilson (1974) found that sepiolite is frequently present in Yucatán, usually in small quantities, but it was the dominant material in some of the samples that they examined, such as one from Edzná (Campeche), a site located south of the region explored in this work.

Figure 2 shows the diffractograms of the samples with a high content or a full content of palygorskite. The similarities between all of them are remarkable. Although this observation may appear naive at first sight because the diffractogram is used to identify the mineral, it should be noted that clay minerals are characterize by a high compositional variability that is often related to stuctural variability and that, in turn, is demonsted in the X-ray diffractogram. In particular, it was noted that although the diffractograms of different palygorskites are similar, their intensities and the total number of peaks are never the same (Chisholm 1990). Recently, Suárez et al. (2007) reported an empirical law that relates the chemical composition of the octahedral sheet of palygorskite with the cell dimensions: the greater the $\mathrm{Mg}$ concentration, the larger is the a parameter. Therefore, differences in composition imply a change in the a parameter, which in turn affects the position of some peaks in the diffractogram. These compositional differences affect mostly the two first peaks, corresponding to the $110\left(2 \theta \approx 8^{\bullet}\right)$ and $200\left(2 \theta \approx 14^{\bullet}\right)$ reflections.

The fact that two different palygorskites present different relative intensities could be related to a different proportion of the two crystallographic phases present in most palygorskites: 


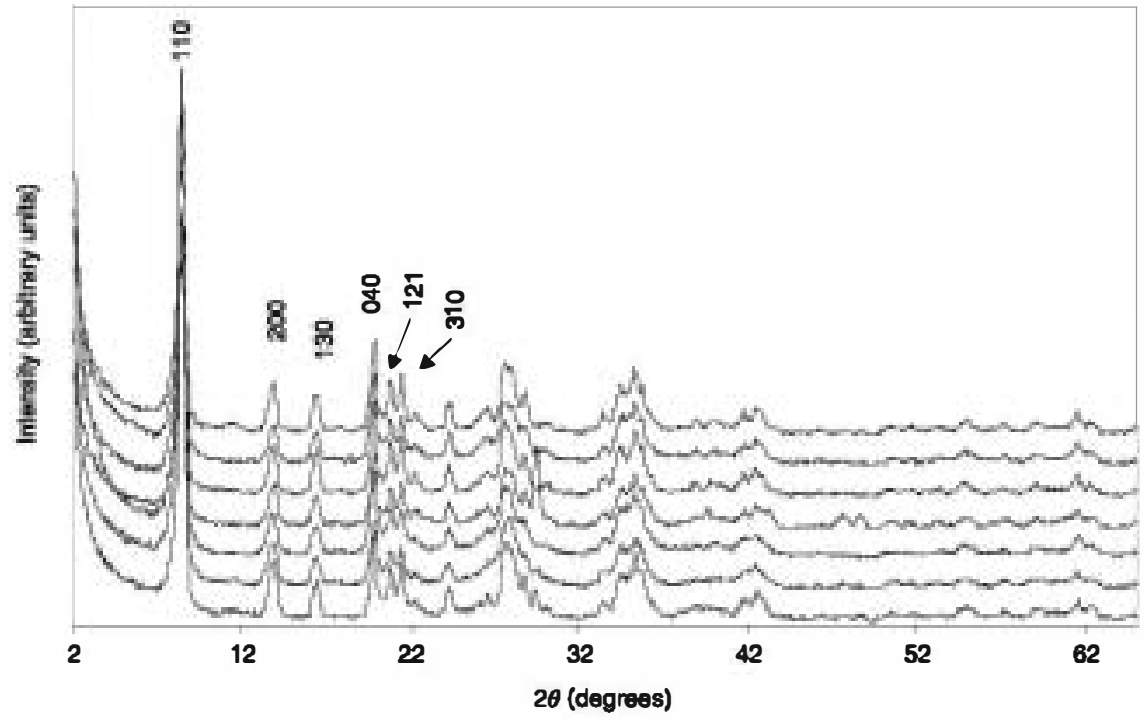

Figure $2 X$-ray diffictograms of the palygorskites with higher purity: from bottom to top, Y1 1 , Y2b, Y3, Y 5, Y6, Y7 and $Y 8$.

monoclinic and orthorhombic (Chirst et al. 1969; Chisholm 1992; Chiari et al. 2003). This is particularly evident in the diffractogram region corresponding to peaks $130\left(2 \theta \approx 16^{\circ}\right)$ and 040, 121 and 310 (in the region $2 \theta=19-22^{\circ}$ ). As all of our samples present similar intensities, their ratio of the two crystallographic phases is very similar, with a slightly higher concentration of the monoclinic phase - we obtaine 55-65\% monoclinic from Rietveld refinement, depending on the fitting conditions, in agreement with Chiari et al. (2003) and Giustetto and Chiari (2004).

From the similarity of the diffractograms amongst the Yucatecan palygorskites, we deduce similar composition, as well as a similar presence of crystallographic phases. These two facts constitute well-defined characteristics of the Yucatecan palygorskites. To confirm the validity of this hypothesis, we calculated peak positions for the 110 and 200 reflections and the relative intensities of the 110, 200, 130, 040, 121 and 310 reflections for the Yucatecan palygorskites and the other reference palygorskites. The scatterplot matrix (Fig. 3) always shows the Yucatecan samples grouped, forming clusters that are distinguished from the others. This confirms the great homogeneity of the Yucatecan palygorskite group with respect to the other palygorskites, both from the compositional and the structural points of view.

The morphology and texture of palygorskite (scanning electron microsc py)

Microtextural images by SEM show that the samples studied look similar and present the characteristic fibrous morphology of palygorskite (Fig. 4). One can appreciate the high purity of the samples. The fibres of palygorskite are joined forming small bundles of $1-5 \mu \mathrm{m}$ in length. These small bundles are arranged in parallel planes, with the $c$-axis (along the fibre axis) randomly oriented. The clay is formed by planar aggregates of bundles (Fig. 4 (b)) showing the characteristic texture of the sedimentary palygorskite. From this point of view, the Yucatán 


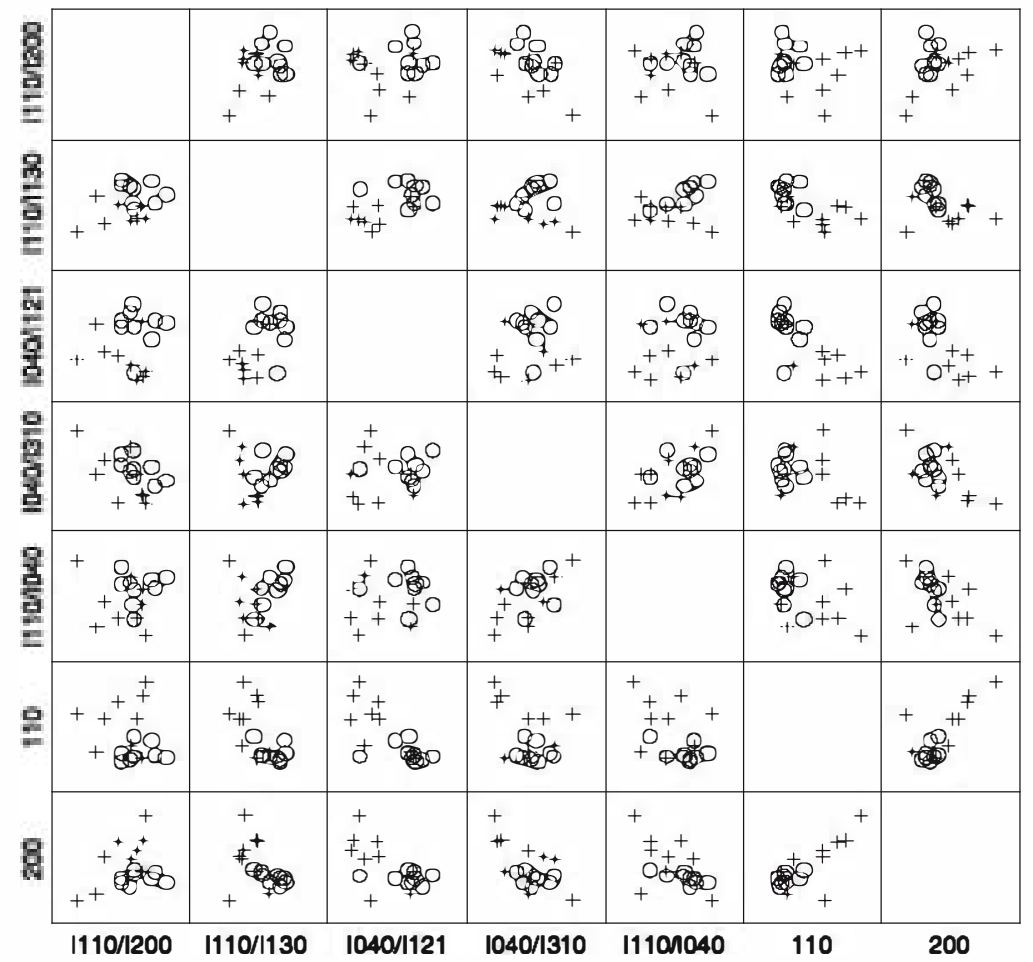

Figure 3 A scatterp lot matrix, which culd be considered as the graphical equivalent of the corre lation matrix, with the projections of the d-spacin of 110 and 200 reflections, which are affected by the composition, as discussed in the text, and the intensities $111.1200,1130,104$ and I121, which culd be related the different ratio of the -rthorh mbic and moclinic phases in palygorskite. Each cell is single plot, where the Yucatecan samples are

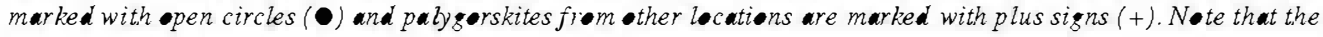
Yucatecan palyorskites (-) roup together in most cells.

palygorskite is similar to the other sedimentary palygorskites used as references (such as Bercimuel, Torrejón or Esquivias).

Although a geological study of the deposit is beyond the scope of this work, the texture of the palygorskites of the Ticul area suggests a depositional formation process from solution. Moreover, the high purity of the palygorskite samples, the absence of quartz and smectites, and the spatial relation of the fibre planes to carbonate levels would also support this origin by direct precipitation from solution. Therefore, there is no sign of any transformation processes in the samples studied here (Y7, Y8 and Y13), even though other authors (Bohor 1975; Isphording 1984; de Pablo-Galán 1996) have proposed that some Yucatecan palygorskites may be the result of diagenesis from dolomite or montmorillonite.

The crystallochemistry of palyorskite

AEM analyses were use to calculate the structural formulae for some Yucatecan palygorskites (Y1a, Y3, Y7, Y8 and Y13). The results are compared with other references and with the ideal palygorskite. In Yucatecan palygorskites, the tetrahedral sheet presents only a very small 


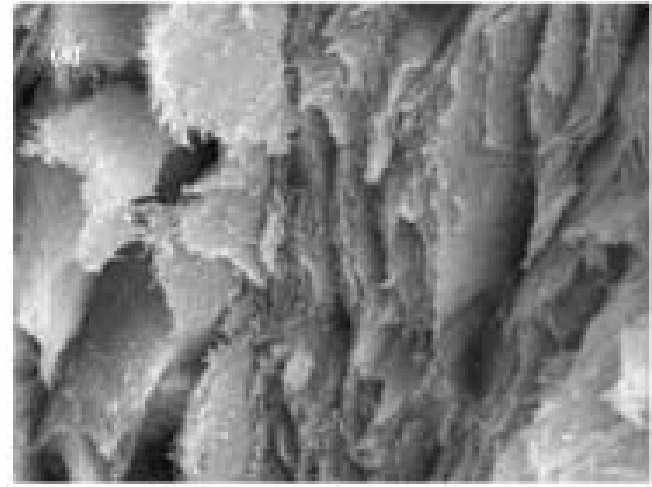

$20 \mu \mathrm{m}$

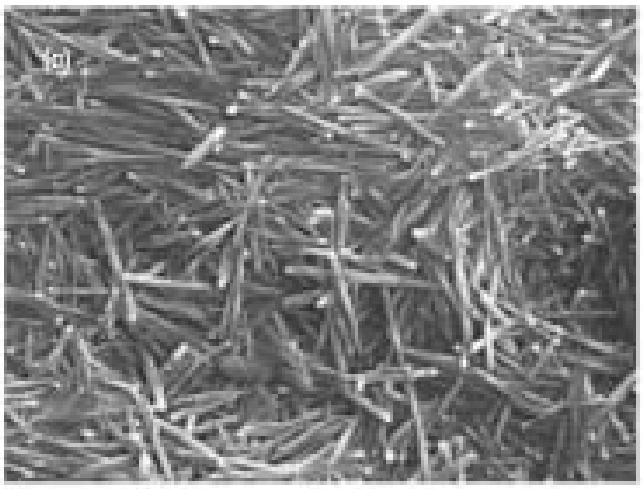

$6 \mu \mathrm{m}$

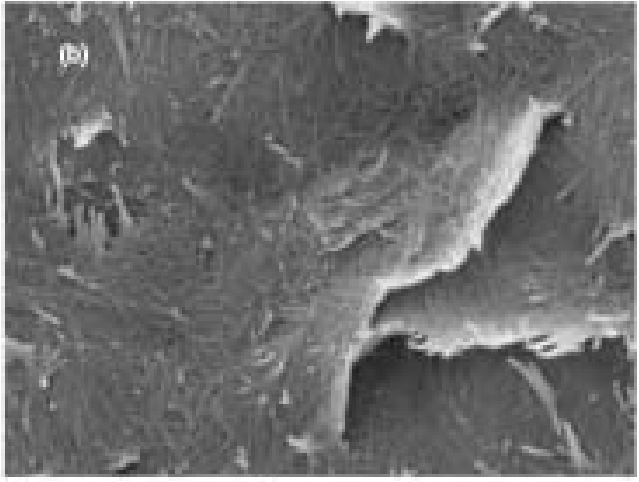

$10 \mathrm{um}$

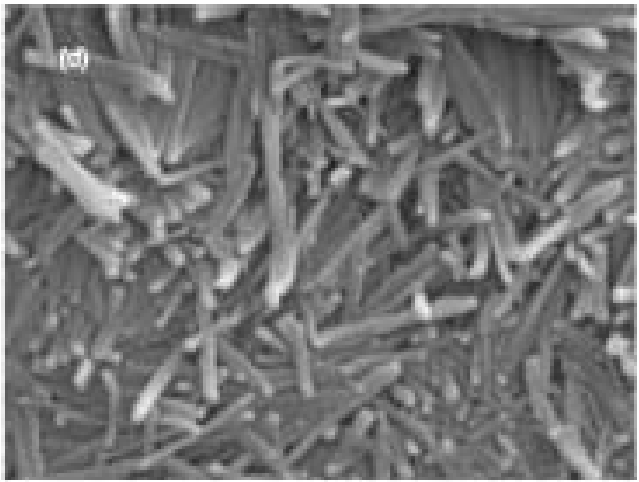

$4 \mathrm{um}$

Figure 4 SEM micrographs. (a) Sample Y8: the arrangement of the fibres forming pallel planes. (b) Sample Y7: a general view of a planar surface that is formed by interbred fibres. (c, d) Samples Y7 and Y 13, respectively. The charcteristic fibrous morphology of palyorskite is evident, showing als a high purity. The palygerskite is structured as superpesed flat layers of fibres. The fibres are randomly oriented in the layer $p$ lanes.

amount of Si substituted by $\mathrm{Al}(7.86<[\mathrm{Si}]<8.04$, where the brackets represent the atomic content). The contents in the octahedral cations are $1.44<\left[\mathrm{Al}_{(\backslash \mathrm{I})}\right]<1.67,2.18<[\mathrm{Mg}]<2.34$ and $\mathbf{0 . 1 4}<\left[\mathrm{Fe}^{3+}\right]<\mathbf{0 . 2 8}$. The similarity among these Yucatecan samples when compared with the reference samples from other locations is demonstrated in Figure 5. The compositional results (see Table 2) clearly show that the palygorskites coming from the different localities in Yucatán have similar octahedral contents, and that they are also similar to other palygorskites, such as those from Attapulgus or Torrejón (Suárez et al. 2007). This confirms the previous results inferred from XRD. All these palygorskites belong to Type II (Suárez et al. 2007), characterized by an $\mathrm{Al}_{(\mathrm{VT})}$ content between 1 and 2 , and with the number of octahedral cations close to 4 (i.e., one vacant octahedral position).

These results give an average formula for the Yucatecan palygorskite as ( $\mathrm{Si}_{7.96} \mathrm{Al}_{\mathbf{0 . 0 7}}$ )

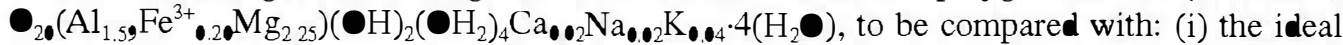
palygorskite $\mathrm{Si}_{8} \mathbf{O}_{2}\left(\mathrm{Al}_{2} \mathrm{Mg}_{2}\right)(\mathrm{H})_{2}\left(\mathrm{OH}_{2}\right)_{4} \cdot 4\left(\mathrm{H}_{2} \mathbf{O}\right)$; (ii) the formula in de Pablo-Galán (1996)

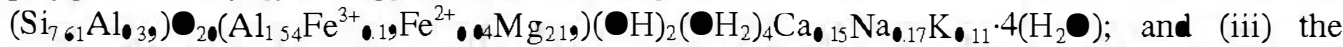



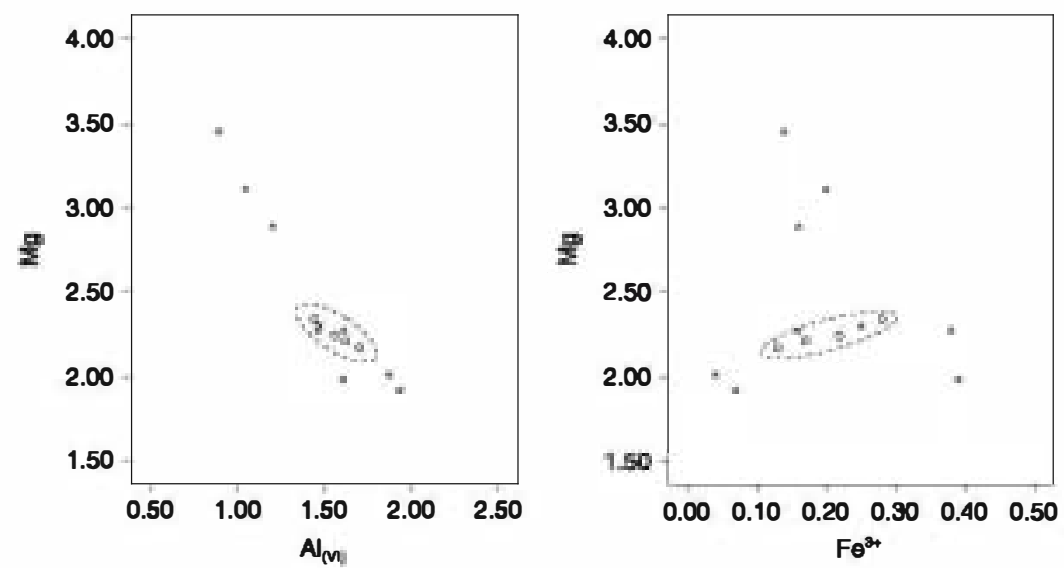

Figure 5 Bivariate plots representing the number of ahedral cations (per half-unit cell) $\bullet$ btained from AEM of -f Yucatd $n$ samples (O) and other reference palyorskites ( $\left.x_{*}^{*}\right)$.

Table 2 The composition of six samples of Yucatecan palyorskites obtained by AEM: $\tau$, Tetrahedial sites; $o$. c tahedral sites; STDV, standard deviation; $N$, number of measurements; $A l_{(I V)}$, luminium in a tetrahedral site; $A l_{(v I)}$ aluminium in an octahedral site

\begin{tabular}{|c|c|c|c|c|c|c|c|c|c|c|c|}
\hline & $S i$ & $A l_{(I V)}$ & $\Sigma \tau$ & $A l_{(V I)}$ & $\mathrm{Fe}^{3+}$ & $M g$ & Ti & $\Sigma o$ & $C a$ & $K$ & $N a$ \\
\hline $\mathrm{Y} \bullet$ & 7.86 & 0.14 & 8.00 & 1.56 & 0.22 & 2.24 & 0.01 & 4.03 & $\bullet .03$ & 0.10 & \\
\hline STDV, $N=15$ & 0.13 & 0.12 & 0.02 & 0.20 & 0.05 & 0.22 & 0.01 & $\bullet .13$ & 0.02 & 0.10 & $\bullet .01$ \\
\hline Y1a & 7.95 & $\bullet .07$ & 8.02 & 1.67 & 0.16 & 2.23 & & 4.06 & 0.03 & & \\
\hline STDV, $N=15$ & 0.10 & 0.06 & 0.05 & 0.13 & 0.06 & 0.20 & & 0.11 & 0.06 & & \\
\hline Y3 & 8.04 & 0.02 & 8.07 & 1.55 & $\bullet .14$ & 2.32 & $\bullet . \bullet 1$ & $4 . \bullet 1$ & $\bullet . \bullet 1$ & 0.04 & $\bullet .03$ \\
\hline STDV, $N=15$ & 0.14 & 0.04 & 0.12 & 0.11 & 0.04 & 0.18 & & 0.11 & 0.02 & 0.04 & 0.06 \\
\hline Y7 & 7.97 & 0.06 & 8.03 & 1.62 & 0.17 & 2.21 & & 4.01 & 0.03 & $\bullet .01$ & 0.07 \\
\hline STDV, $N=15$ & 0.12 & 0.09 & 0.05 & 0.13 & 0.08 & 0.15 & & 0.14 & 0.04 & $\bullet .01$ & $\bullet .10$ \\
\hline Y8 & 7.92 & 0.09 & $8 . \bullet 1$ & 1.67 & 0.2 & 2.18 & $\bullet . \bullet 1$ & 4.05 & $\bullet . \bullet 1$ & 0.07 & \\
\hline STDV, $N=12$ & 0.10 & 0.09 & 0.02 & 0.08 & 0.03 & 0.13 & & 0.08 & 0.00 & 0.03 & \\
\hline Y13 & 7.99 & 0.04 & 8.03 & 1.44 & 0.28 & 2.34 & & 4.07 & 0.01 & & 0.02 \\
\hline STDV, $N=$ & 0.12 & 0.14 & 0.05 & $\bullet .14$ & 0.11 & 0.17 & & $\bullet .13$ & & & \\
\hline Mean Yuca tán & 7.96 & 0.07 & 8.03 & 1.59 & 0.2 & 2.25 & $<\bullet .01$ & 4.04 & 0.02 & 0.04 & 0.02 \\
\hline
\end{tabular}

formula calculate using the major element concentrations resulting from geochemistry analysis

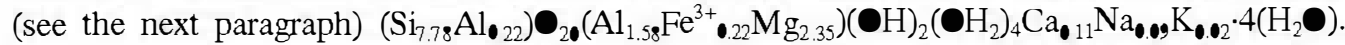
The differences found do not seem to be dramatic considering the diversity of techniques employed and the intrinsic compositional variability of the palygorskite. Moreover, it is remarkable that the octahedral content is similar for the three formulae.

Lastly, it should be note that the AEM method needs only a microsample, which makes it very suitable technique for analysis of Maya blue pigments from archaeological samples. The data presented in Table 2 will allow us to know whether or not the archaeological pigments present a crystal chemistry that is compatible with the Yucatán one. 


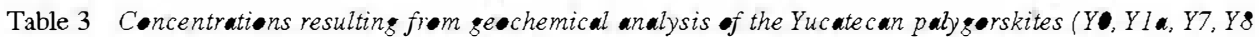
and Y13) and other palygorskites from different rigins. Numbers shown in italics are upper limit

Z Y YI $\quad Y 7$ Y\& YI3 LISL TOR EII ATT SNE BERC TRA

LISL

\section{Major $(\%)$}

Si $\quad 14 \quad 24.662$

Al 13

$\mathrm{Fe} \quad 26$

5.396

25.470

24.770

6.718

4.142

1.434

1.294

Mn 25

0.002

0.006

6.006

7.266

1.272

0.264

0.015

0.208

0.473

0.192

0.103

0.094

0.004

0.004

\begin{tabular}{|c|c|c|c|c|c|c|c|c|}
\hline 5.862 & 25.578 & 25.559 & 27.007 & 12.539 & 25.484 & 25.386 & 23.733 & 26.124 \\
\hline 5.406 & 4.877 & 6.237 & 3.883 & 1.714 & 6.099 & 6.136 & 8.152 & 3.793 \\
\hline 1.574 & 1.546 & 0.615 & 1.700 & 0.650 & 2.721 & 0.783 & 4.022 & 1.238 \\
\hline 106 & 0.003 & 0.018 & 0.067 & 0.032 & 0.094 & 0.037 & 0.072 & 0.263 \\
\hline 259 & 6.729 & 5.481 & 4.908 & 3.202 & 5.294 & 5.355 & 2.810 & 8.104 \\
\hline 114 & 0.765 & 0.207 & 3.130 & 22.270 & 0.993 & 0.465 & 2.273 & 0.121 \\
\hline 185 & 0.185 & 0.045 & 0.126 & 0.022 & 0.134 & 0.141 & 0.245 & 0.045 \\
\hline .531 & 0.091 & 0.274 & 0.664 & 0.465 & 1.038 & 0.249 & 1.868 & 0.149 \\
\hline 143 & 0.127 & 0.207 & 0.278 & 0.071 & 0.269 & 0.014 & 0.349 & 0.045 \\
\hline .013 & 0.004 & 0.031 & 0.009 & 0.013 & 0.009 & 0.009 & 0.022 & 0.048 \\
\hline
\end{tabular}

Trace $\left(\mu g g^{-1}\right)$

\begin{tabular}{|c|c|c|c|c|c|c|c|c|c|c|c|c|c|}
\hline $\mathrm{Be}$ & 4 & $<1$ & $<1$ & 1 & 1 & $<1$ & $<1$ & 2 & $<1$ & 2 & 1 & 3 & 1 \\
\hline Sc & 21 & 5 & 7 & 6 & 7 & 6 & 16 & 6 & 2 & 9 & 6 & 13 & 4 \\
\hline V & 23 & 74 & 90 & 38 & 27 & 63 & 167 & 41 & 39 & 75 & 75 & 124 & 14 \\
\hline $\mathrm{Cr}$ & 24 & 40 & 100 & 30 & 50 & 40 & 30 & 40 & $<2$ & 50 & $<2$ & 80 & $<2$ \\
\hline Co & 27 & 1 & 1 & 5 & 3 & 2 & 4 & 8 & $<1$ & 10 & 34 & 24 & 34 \\
\hline $\mathrm{Ni}$ & 28 & 20 & $<2$ & 40 & 40 & 20 & $<2$ & $<2$ & $<2$ & 20 & $<2$ & 40 & 100 \\
\hline $\mathrm{Cu}$ & 29 & $<1$ & $<1$ & 20 & $<1$ & $<1$ & 10 & 10 & $<1$ & 10 & $<1$ & 30 & 40 \\
\hline $\mathrm{Zn}$ & 30 & $<3$ & $<3$ & $<30$ & 40 & 3 & 30 & 40 & $<3$ & $<3$ & $<3$ & 60 & 30 \\
\hline $\mathrm{Ga}$ & 31 & 12 & 17 & 13 & 14 & 12 & 32 & 11 & 5 & 14 & 23 & 22 & 22 \\
\hline $\mathrm{Ge}$ & 32 & 0.7 & 1 & 1.1 & 1.3 & 0.6 & 0.8 & 1 & 1.2 & 1 & 2.5 & 1.9 & 10 \\
\hline As & 33 & $<5$ & 8 & $<5$ & 7 & $<5$ & $<5$ & 5 & $<5$ & 11 & $<5$ & 9 & 5 \\
\hline $\mathrm{Rb}$ & 37 & 36 & 13 & 36 & 41 & 11 & 11 & 49 & 28 & 66 & 9 & 130 & 11 \\
\hline $\mathrm{Sr}$ & 38 & 8 & 6 & 18 & 7 & 18 & 30 & 77 & 90 & 42 & 18 & 91 & 8 \\
\hline $\mathrm{Y}$ & 39 & 1.2 & 1.9 & 1.5 & 5.6 & 1.1 & 1.7 & 21.4 & 6.6 & 20.8 & 0.8 & 30.2 & 34.4 \\
\hline $\mathrm{Zr}$ & 40 & 153 & 224 & 153 & 135 & 104 & 45 & 165 & 38 & 12 & 11 & 152 & 65 \\
\hline $\mathrm{Nb}$ & 41 & 7.2 & 9.1 & 6.2 & 7.6 & 4.2 & 6.9 & 7.9 & 3 & 7.2 & 0.6 & 11.9 & 13.2 \\
\hline Mo & 42 & $<2$ & $<2$ & $<2$ & $<2$ & $<2$ & $<2$ & $<2$ & $<2$ & $<2$ & $<2$ & $<2$ & $<2$ \\
\hline $\mathrm{Ag}_{\mathbf{g}}$ & 47 & $<.5$ & $<.5$ & $<.5$ & $<.5$ & $<.5$ & $<.5$ & $<.5$ & $<.5$ & $<.5$ & $<.5$ & $<.5$ & $<.5$ \\
\hline In & 49 & $<.1$ & $<.1$ & $<.1$ & $<.1$ & $<.1$ & $<.1$ & $<.1$ & $<.1$ & $<.1$ & $<.1$ & $<.1$ & $<.1$ \\
\hline Sn & 50 & 2 & 4 & 2 & 3 & 3 & $<1$ & 3 & 2 & 3 & $<1$ & 5 & 2 \\
\hline $\mathrm{Sb}$ & 51 & $<.2$ & $<2$ & 2.2 & $<.2$ & $<.2$ & $<.2$ & $<.2$ & $<.2$ & $<.2$ & 3.3 & $<.2$ & $<.2$ \\
\hline Cs & 55 & 2.9 & 1.3 & 2.2 & 2.9 & 1.3 & 0.2 & 4.2 & 1.8 & 6.1 & 0.3 & 9.9 & 1.8 \\
\hline $\mathbf{B a}$ & 56 & 18 & 21 & 33 & 44 & 26 & 53 & 495 & 121 & 546 & 15 & 564 & 33 \\
\hline Hf & 72 & 3.9 & 5.7 & 3.7 & 4.1 & 2.8 & 0.9 & 4.4 & 1.2 & 3.3 & 0.2 & 4.1 & 1.4 \\
\hline $\mathrm{Ta}$ & 73 & 0.93 & 0.94 & 0.47 & 0.75 & 0.43 & 0.48 & 0.88 & 0.39 & 0.8 & 0.03 & 1.11 & 0.43 \\
\hline W & 74 & 0.7 & 0.6 & 0.7 & $<.5$ & 0.7 & 3.2 & 1.3 & 1.8 & 2.9 & $<.5$ & 2 & 2 \\
\hline $\mathrm{Tl}$ & 81 & 0.12 & $<\bullet .05$ & 0.1 & 0.16 & 0.08 & $<\bullet .05$ & 0.32 & 0.22 & 0.53 & 0.15 & 0.86 & 0.39 \\
\hline $\mathrm{Pb}$ & 82 & $<5$ & $<5$ & $<5$ & $<5$ & $<5$ & $<5$ & 8 & $<5$ & 11 & $<5$ & 23 & $<5$ \\
\hline $\mathrm{Bi}$ & 83 & 0.2 & 0.9 & 0.2 & 0.4 & 0.4 & 0.1 & 0.5 & $<0.1$ & 0.6 & $<.1$ & 1 & 0.2 \\
\hline Th & 90 & 3.3 & 8.05 & 3.92 & 11.3 & 2.61 & 0.53 & 8.7 & 5.01 & 8.21 & 0.39 & 13.6 & 6.05 \\
\hline $\mathrm{U}$ & 92 & 0.92 & 0.54 & 0.26 & 0.46 & 0.21 & 0.2 & 2 & 0.74 & 1.69 & 0.22 & 1.76 & 0.21 \\
\hline \multicolumn{14}{|c|}{$L R E E\left(\mu g g^{-1}\right)$} \\
\hline $\mathrm{La}$ & 57 & 1.83 & 1.93 & 1.81 & 10 & 1.45 & 4.36 & 25 & 10.7 & 25.9 & 0.57 & 35.3 & 15.9 \\
\hline $\mathrm{Ce}$ & 58 & 3.64 & 4.41 & 6.0 & 17.3 & 2.97 & 12.8 & 51.6 & 30.3 & 52.5 & 2.47 & 84.8 & 29.4 \\
\hline $\operatorname{Pr}$ & 59 & 0.39 & 0.44 & 0.48 & 3.05 & 0.32 & 1.22 & 6.38 & 2.62 & 6.24 & 0.15 & 8.28 & 3.64 \\
\hline Nd & 60 & 1.24 & 1.56 & 1.59 & 10.3 & 1.08 & 4.56 & 23.6 & 9.25 & 23 & 0.51 & 30 & 13.7 \\
\hline $\mathrm{Sm}$ & 62 & 0.22 & 0.29 & 0.29 & 1.93 & 0.2 & 0.79 & 4.52 & 1.9 & 4.5 & 0.11 & 5.82 & 3.02 \\
\hline
\end{tabular}




\begin{tabular}{|c|c|c|c|c|c|c|c|c|c|c|c|c|c|}
\hline & $Z$ & $Y \bullet$ & Yla & $Y 7$ & Y8 & Y13 & LISL & $T \bullet R$ & E11 & $A T T$ & SNE & $B E \boldsymbol{R} C$ & $T R A$ \\
\hline \multicolumn{14}{|c|}{$H R E E\left(\mu g^{-1}\right)$} \\
\hline $\mathrm{Eu}$ & 63 & 0.039 & 0.053 & 0.052 & 0.223 & 0.036 & 0.248 & 0.899 & 0.254 & 0.97 & 0.024 & 1.41 & •. 413 \\
\hline $\mathrm{Gd}$ & 64 & 0.15 & 0.23 & 0.22 & 1.3 & 0.14 & 0.51 & 3.53 & 1.53 & 3.81 & 0.11 & 5.2 & 3.13 \\
\hline $\mathrm{Tb}$ & 65 & 0.03 & 0.05 & 0.04 & 0.21 & 0.03 & 0.07 & ๑. 6 & 0.25 & 0.69 & 0.02 & 0.97 & $\bullet .63$ \\
\hline Dy & 66 & $\bullet .2$ & 0.31 & 0.23 & 1.14 & 0.19 & 0.38 & 3.51 & 1.39 & 3.73 & $\bullet .1$ & 5.81 & 4.32 \\
\hline Ho & 67 & 0.04 & 0.07 & 0.05 & 0.22 & 0.04 & $\bullet .06$ & 0.68 & 0.25 & 0.72 & 0.02 & 1.14 & 0.98 \\
\hline Er & 68 & 0.15 & 0.24 & $\bullet .16$ & $\bullet .67$ & $\bullet .15$ & 0.16 & 1.97 & $\bullet .69$ & 2.15 & 0.06 & 3.3 & 3.26 \\
\hline $\mathrm{Tm}$ & 69 & 0.032 & 0.045 & 0.032 & 0.119 & 0.026 & 0.02 & 0.291 & 0.102 & 0.321 & 0.01 & 0.484 & 0.527 \\
\hline $\mathrm{Yb}$ & 70 & 0.25 & 0.33 & 0.25 & 0.8 & 0.21 & 0.11 & 1.88 & 0.62 & 2.08 & 0.08 & 2.99 & 3.6 \\
\hline $\mathrm{Lu}$ & 71 & 0.039 & 0.059 & 0.053 & 0.162 & 0.04 & 0.015 & 0.277 & 0.087 & 0.302 & 0.014 & 0.422 & 0.58 \\
\hline
\end{tabular}

\section{The gechemistry of palygorskite}

The statistical analysis of the chemical data (concentration of major elements) as well as the trace elements may classify the samples in groups with different chemical fingerprints related to the geology of the deposits. Five Yucatecan samples, Y0, Y 1a, Y7, Y 8 and Y13, were selected for this study, together with seven palygorskites from other origins. The aim is to test whether all samples from Yucatán have similar contents in trace elements or, on the contrary, whether their contents in trace elements vary from one sample to another, thus depending on the deposit.

The Yucatán samples are characterized by a low content in rare earth elements, both for light rare earth elements (LREE) and for heavy ones (HREE) (Table 3). Also, Y and U contents are particularly low in Yucatecan samples. In contrast, $\mathrm{Hf}$ and $\mathrm{Zr}$ are more concentrated in Yucatecan palygorskites than in the other palygorskites studied. Amold et al. (2007) found discrepancies in values of concentrations in $\mathrm{Hf}$ and $\mathrm{Zr}$ measured using two different techniques, one more sensitive to the bulk (INAA), and the other to the surface (LA-ICP-MS). They suggeste the possible presence of minute zircon grains, more represented in the bulk. The sample from the cen te in Sacalum presents the highest values $\left(17 \mu \mathrm{g} \mathrm{g}^{-1}\right.$ for $\mathrm{Ce}, 10 \mu \mathrm{g} \mathrm{g}^{-1}$ for La and $\mathbf{N d}$ ), several orders of magnitude greater than the others. Also, the content in $\mathrm{Y}$ is especially low in these samples. The values of both the elements and major elements are good parameters to distinguish between Yucatecan and non-Yucatecan samples, as seen in Figure 6. Moreover, it is also possible to differentiate the Yucatán group when looking at several bivariate plots (Fig. 7) or in a scatterplot matrix (Fig. 8). Therefore, the concentration of both trace and major elements in palygorskite defines a chemical fingerprint that characterizes the samples coming from Yucatán.

Arnold et al. (2007) proposed to use trace element analysis (INAA and LA-ICP-MS) for provenance analysis of Maya blue pigment. They analysed many samples, most of them from the Yucatán area, and distinguished provenance groups within the Yucatán peninsula (Sacalum, Chapab and Uxmal) when looking at the bivariate plots of Rb versus V, Ni or Mn. Although we have analyse only one representative of each origin (see Table 3), we have verified that they present a similar trend. Our Y $\mathbf{0}, Y 7$ and $Y 8$ samples $(1.4<\log 10([R b])<1.8)$ group quite well with Amold's Sacalum group, and our Y la and Y13 are close to his Uxmal group. This is consistent with the geographic origin. The Yucatecan samples, as compared with all the rest, 

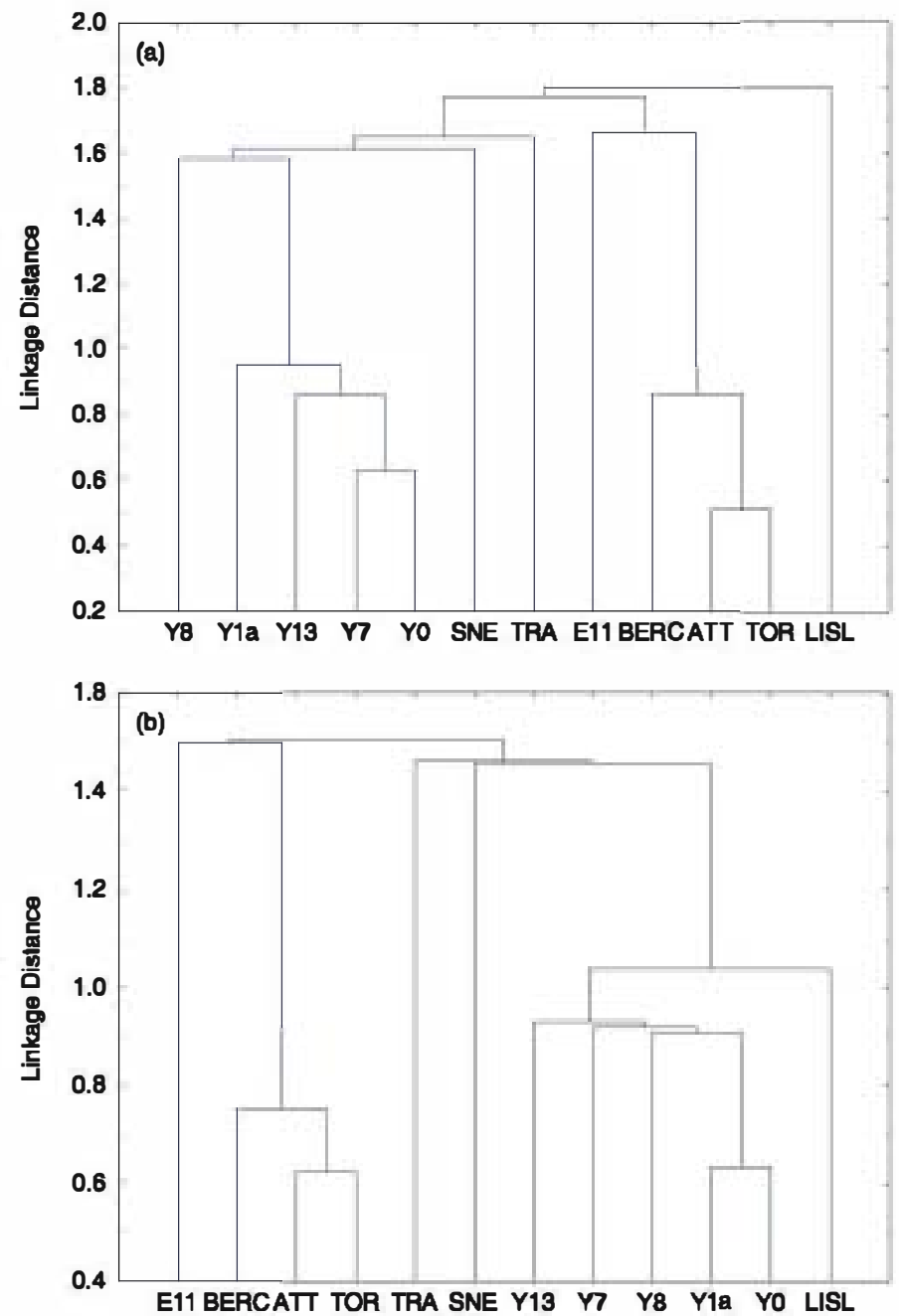

Figure 6 Dendrograms built using the gechemistry nalysis ( $\log _{10}$ of concentrations) of different palyg rskites from

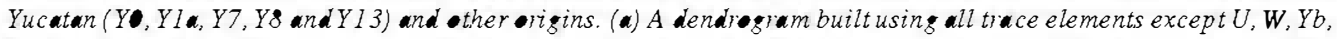
Er, $y, G$ and Sm. (b) A dendrogram built using major elements. It can be appreciated that Yucatecan palygorskites are always grouped together.

are particularly low in Mn, and this could be a simple fingerprint for addressing or excluding Yucatecan origins. In addition to Mn, the Yucatecan samples are different from the Attapulgus one (the only one from the same continent) because they are poor in several other elements (Ti, Sr, Y, Ba, W and Pb).

\section{SUMMARY AND CONCLUSIONS}

Several palygorskites of great purity have been collected in several places in the Yucatán peninsula, all located in a radius of $40 \mathrm{~km}$ around the archaeological site of Uxmal. Some of 

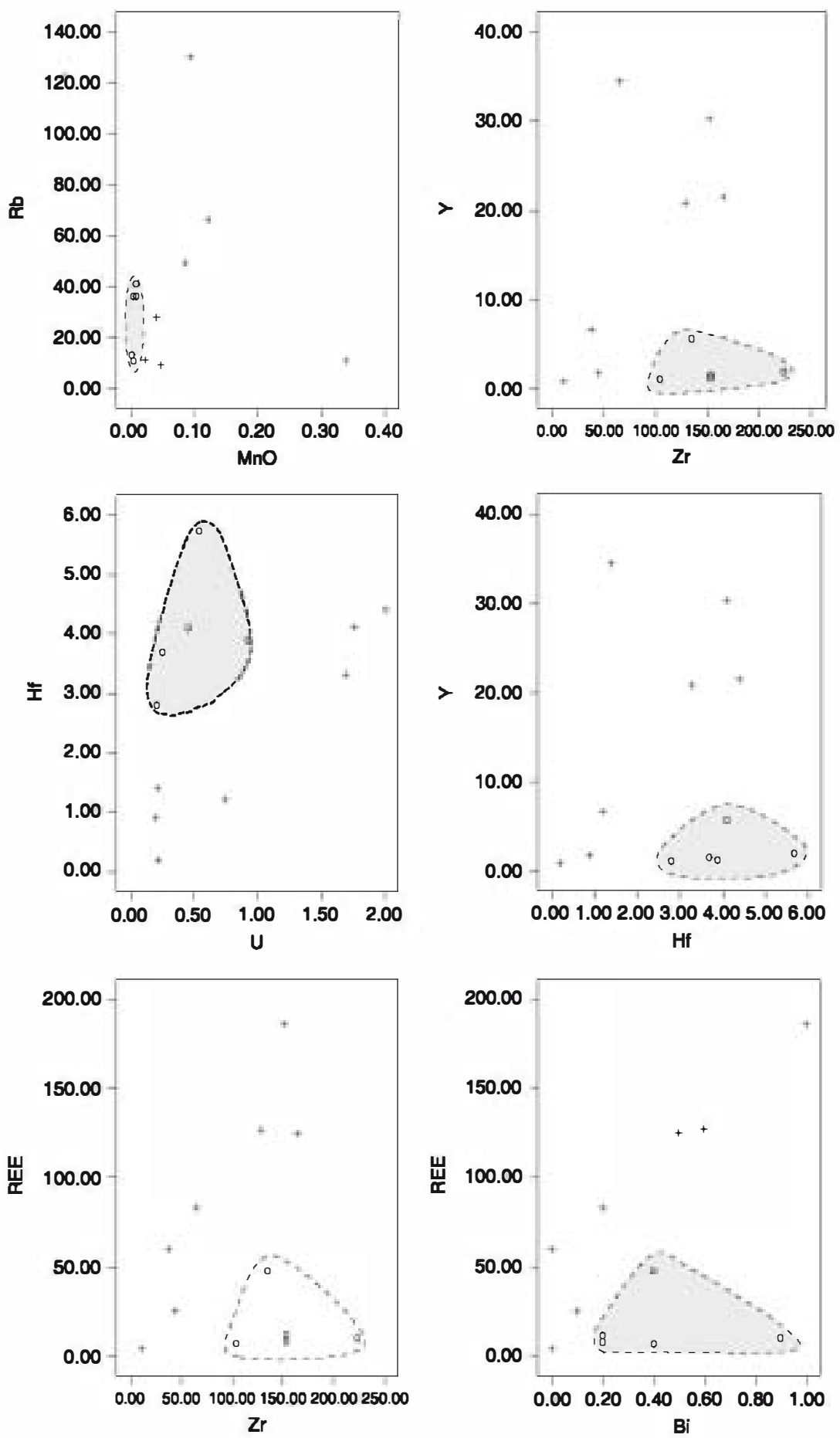

Figure 7 Bivariate plots representing the trace element concentrations corresponding to data from chemical analyses of Yucatecan samples (O) and other palyorskites used for comparis (+). 


\begin{tabular}{|c|c|c|c|c|c|c|c|}
\hline & $\phi^{n}$ & $e^{x^{x}}$ & ס & $x^{n}$ & $8^{n "}$ & * & $=B^{x}$ \\
\hline$\sigma^{x}$ & & $e^{x^{x}}$ & $x^{2} x^{n x}$ & مُ & $8^{n}$ & $\begin{array}{c}x x^{x} \\
x^{x} 8 \\
8\end{array}$ & $x_{0}^{x}$ \\
\hline$\rho^{x}$ & $e^{x}$ & & 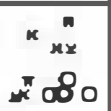 & $\begin{array}{l}{ }_{*}^{x} \\
\sin 80\end{array}$ & $8^{3}$ & $\begin{array}{l}x_{x} \\
x^{n} x\end{array}$ & ${ }^{x}{ }^{\frac{x}{x_{x}}}$ \\
\hline $\begin{array}{l}\operatorname{lo}_{x} \times x \\
x^{n-n}\end{array}$ & $\begin{array}{l}0 \\
\theta^{0}=x \\
x^{*}=\end{array}$ & $\int_{y^{n}}^{0} x_{x}^{x}$ & & & $\begin{array}{l}0 \\
\int^{*}=x \\
x^{*}\end{array}$ & $\underbrace{0}_{x x_{x}^{x}}=$ & $\begin{array}{l}0 \\
8^{*} \\
8^{*} \\
x^{*}\end{array}$ \\
\hline $\begin{array}{l}0 \\
80 \\
x^{x} x^{x}\end{array}$ & $8_{x^{x / 7}}^{0} x x$ & $\log _{x^{x}} x_{x} x$ & & & $\stackrel{\circ}{8} x^{\circ}$ & ${ }_{x}^{0}$ & ק. \\
\hline$c^{\circ}$ & $\infty^{x}$ & $a^{\pi_{n}}$ & $\begin{array}{c}x_{x \times}^{n} \\
x+\infty 0\end{array}$ & $\begin{array}{l}n \\
\times 10 \\
\times 10\end{array}$ & & $\begin{array}{l}{ }^{K} \times n \\
\times x \times\end{array}$ & $x^{x} x_{x \times x}^{x}$ \\
\hline $\cos _{x^{x}}{ }^{x}$ & $P_{y}^{x}{ }^{x}$ & $\log ^{x} x_{x}^{x}$ & • & $\begin{array}{l}\text { "x } \\
=0\end{array}$ & $P_{x}^{x}{ }^{x} x$ & & ${ }^{x}{ }^{x}$ \\
\hline 8. & $8^{\frac{x}{x} x}$ & $88^{\frac{x}{x} x}$ & $\begin{aligned} & x \\
= & 30\end{aligned}$ & $\begin{array}{r}x \\
8 \\
80 \\
8\end{array}$ & $8^{\frac{x}{x x}}=$ & $g_{x}^{x} \times x$ & \\
\hline
\end{tabular}

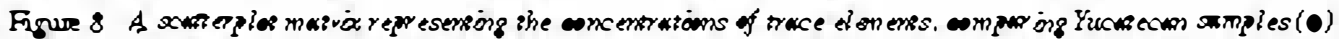

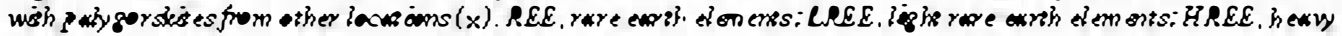
race exat? elements.

these places were well documented, but others are reported here for the first time. The abundarce of palygorckite in the samples collected allows as to affirm that pa.ygor ckite is a frequent mineral in the siudied area and can easily found at alinost surface level. From this fact, it can be argued that the ancient Maya could have extracted paygorskite from different places in this area. As pa.ygorskite occurs close to the surface, evidence of the extraction could have been removed by the effects of erosion and vegetation over a nurnber of centuries This supports the idea that paygorskite is widespread in Yucating at least intle studied area, as discussed by Littmann (1982) and Amold et $\times$ ?. (2007).

All of the Yucatecan paygorskites present very similar diffractograms, and show marked differences with respect to other paygorskites ana.ysed. This implies compositiona. and structura. hornogeneity, moking it irmpossible from this point of view to separate them into provenance groups within Yucatan, but they can be easily differentiated from other origins. The crystalochemical analysis confirmed this result and a.lowed as to obtain a mean

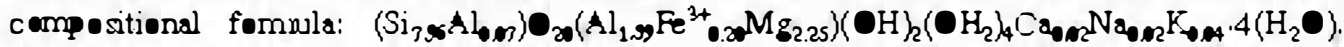
Yucatecan pa.ygorskites a.se contoin trace elements that differentiate them easily from the - ther origins. Eventua.ly, careful analyssis of trace elenents could be used to further determine

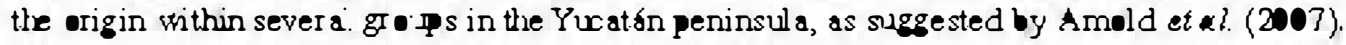
The results presented here will be used when studying archaeologic a. Maya blue pignents in 
order to check whether the palygorskite used in the pigment, either from Maya or other Mesoamerican regions, could have originated from this area.

\section{ACKNOWLEDGEMENTS}

The samples were collected in a visit to Yucatán during the sabbatical leave of MSR at the Universidad Autónoma Metropolitana-Iztapalapa (Mexico), which is acknowledged for financial support. Xim Bokhimi provided us with the sample from Tepakan, Campeche. We also acknowledge financial support from the Spanish CICYT (project CGL2006-09843) and the Servicio de Investigación de la UCM (Grupo 9103B6).

\section{REFERENCES}

Amold, D. E., 1998, Ceramic ethnoarchaeology at Ticul, Yucatan, Mexico, The Society for Archaelogical Sciences Bulletin, 21; http://www.socarchsci.org/bulletin/9902/9902 j.htm

Amold, D. E., 2005, Maya blue and palygorskite: a second possible Pre-Columbian source, Ancient Meseame rica, 16, 51-62.

Amold, D. E., and Bohor, B. F., 1975, Attapulgite and Maya blue. An ancient mine comes to light, Arche•l•gy, 28, 23-9.

Amold, D. E., Neff, H., Glascock, M. D., and Speakman, R. J., 2007, Sourcing the palygorskite used in Maya blue: a pilot study comparing the results of INAA and LA-ICP-MS, Latin American Antiquity, 18(1), 44-58.

Bohor, B. F., 1975, Attap ulgite in Yucatan, Instituto de Geología, UNAM, Mexico DF.

Chiari, G., Giustetto, R., and Ricchiardi, G., 2003, Crystal structure refinement of palygorskite and Maya blue from molecular modelling and powder synchrotron diffraction, Eurepen Journal of Mineralogy, 15(1), 21-33.

Chirst, C. L., Hathaway, J. C., Hostler, P. B., and Shepard, A. O., 1969, Palygorskite: new X-ray data, American Mineralogist, 54, 198-205.

Chisholm, J. E., 1990, An X-ray powder-diffraction study of palygorskite, Canadian Mineralogist, 28, 329-39.

Chisholm, J. E., 1992, Powder-diffraction patterns and structural models for palygorskite, Canadian Mineralogist, 30 , 61-73.

de Pablo-Galán, L., 1996, Palygorskite in Eocene-Oligocene lagoonal environment, Yucatán, Mexico, Revist ta Mexican de Ciencias Gelogicas, 13(1), 94-103; http://satori.geociencias.unam.mx/13-1/(6)de_Pablo.pdf

Folan, W. J., 1969, Sacalum, Yucatan: a pre-hispanic and contemporary source of attapulgite, American Antiquity, 34(2), 182-3.

García Romero, E., Suáez, M., Oyarzun, R., López-García, J. A., and Regueiro, M., 2006, Formation of palygorskite in secondary faults from a large shear zone of Miocene age (Serrata de Níjar, SE Spain), Clays Clay Minerals, 54(3), 324-32.

Gettens, R. J., 1962, An unsolved problem in ancient pigments, Americ Antiquity, 7(4), 557-64.

Giustetto, R., and Chiari, G., 2004, Crystal structure refinement of palygorskite from neutron powder diffraction, Eurøpean Journal of Mineral॰ gy, 16, 521-32.

Giustetto, R., Llabres i Xamena, F. X., Ricchiardi, G., Bordiga, S., Damin, A., Gobetto, R., and Chierotti, M. R., 2005, Maya blue: a computational and spectroscopic study, Journal of Physical Chemistry B, 109(41), 19360-8.

Isphording, W. C., 1984, The clays from Yucatán, Mexico; a contrast in genesis, in Palygorskite-sepi-lite •ccurrences, genesis and uses (eds. A. Singer and E. Galán), 75-86, Developments in Sedimentology 37, Elsevier, Amsterdam.

Isphording, W. C., and Wilson, E. M., 1974, The relationship of 'volcanic ash,' sak lu'um, and palygorslite in northem Yucatan Maya ceramics, American Antiquity, 39(3), 483-8.

Littmann, E. R., 1982, Maya blue - further perspectives and the possible use of indigo as the colorant, American Antiquity, 47(2), 404-8.

Morán-Zenteno, D., 1994, The geløgy of the Mexic Republic, AAPG Studies in Geology, American Association of Petroleum Geologists, Tulsa, OK.

Reyes-Valerio, C., 1993, De Benamp al Temp lo Mayor. El azul maya en Meseamerica, siglo XXI editores, Mexico DF.

Sabloff, J. A., and Rathje, W. L., 1975, The rise of a Maya merchant class, Scientific American, 233(4), 72-83. 
Sánchez del Río, M., Martinetto, P., Reyes-Valerio, C., Dooryhée, E., and Suárez, M., 2006a, Synthesis and acid-resistance of the Maya blue pigment, Archaemetry, 48, 115-30.

Sánchez del Río, M., Picquart, M., Haro-Poniatowski, E., van Elslande, E., and Uc, V. H., 2006b, On the Raman spectrum of Maya blue, Jøurnal of Raman Spectroscopy, 37, 1046-53.

Sánchez del Río, M., Sodo, A., Eeckhout, S., Neisius, T., Martinetto, P., Dooryhée, E., and Reyes-Valerio, C., 2005, Fe K-edge XANES of Maya blue pigment, Nuclear Instruments and Methods B, 238, 50-4.

Scarborough, V. L., and Gallopin, G. G., 1994, A water storage adaptation in the Maya lowlands, Science, 251(4), 658-62.

Shepard, A. O., 1962, Maya blue: alternative hypothesis, Americ Antiquity, 27, 565-6.

Shepard, A. O., and Gottlieb, H. B., 1962, May blue: alternative hyp thesis, Notes from a Ceramic Laboratory 1, Camegie Instution of Washington, Washington, DC.

Suárez, M., and García Romero, E., 2006, Macroscopic palygorskite from volcanic complex of Lisbon, Europen Journal of Minera logy, 18(1), 119-26.

Suárez, M., García-Romero, E., Sánchez del Río, M., Dooryhée, E., and Marinetto, P., 2007, The effect of the octahedral cations on the dimensions of the palygorskite cell, Clay Minerals, 42, $287-97$.

Tagle, A. A., Paschinger, H., Richard, H., and Infante, G., 1990, Maya blue: its presence in Cuban Colonial wall paintings, Studies in Conservation, 35, 156-9.

Viseras, C., and López-Galindo, A., 1999, Pharmaceutical applications of fibrous clays (sepiolite and palygorskite), Applied Clay Science, 14, 69-82.

Wolfgang, S., Gerta, K., Thierry, A., Markus, H., Doris, S., Georg, I., and Utz, K., 2004, Yaxcopoil-1 and the Chicxulub impact, International Journal of Earth Sciences, V93(6), 1042-65. 